https://helda.helsinki.fi

\title{
Takaisin oikealle raiteelle
}

\section{Salminen, Stela}

2021

Salminen, S 2021, ' Takaisin oikealle raiteelle ', Kuntoutus, Vuosikerta. 44 , Nro 2 , Sivut 82-84 . https://doi.org/10.37451/kuntoutus.109484

http://hdl.handle.net/10138/334123

https://doi.org/10.37451/kuntoutus. 109484

publishedVersion

Downloaded from Helda, University of Helsinki institutional repository.

This is an electronic reprint of the original article.

This reprint may differ from the original in pagination and typographic detail.

Please cite the original version. 


\section{TAKAISIN OIKEALLE RAITEELLE}

Työuupumuksesta on tullut yksi nyky-yhteiskunnan yleisimmistä työelämän ongelmista. Pelkkä vilkaisu tiedotusvälineisiin riittää antamaan kuvan tilan yleisyydestä ja haitallisista vaikutuksista työntekijöiden terveyteen, työkykyyn ja ihmissuhteisiin.

Globalisaatio, työn tehostuminen ja taloudellisen kasvun tavoittelu ovat johtaneet työntekijöihin kohdistuvien vaatimusten lisääntymiseen ja paineeseen sopeutua jatkuviin muutoksiin. Tämän seurauksena ammatillinen stressi kasautuu, jättää vähemmän aikaa toipumiseen ja johtaa lopulta työuupumuksen kehittymiseen. Työuupumus on stressiperäinen tila, jota luonnehtii uupumusasteinen väsymys, kyynisyys ja alentunut ammatillinen itsetunto. Suomessa vuonna 2011 tehdyn kansallisen tutkimuksen mukaan kaksi prosenttia miehistä ja kolme prosenttia naisista on kärsinyt vakavasta työuupumuksesta, kun taas lievästä työuupumuksesta kärsineiden osuus oli paljon suurempi: 23 prosenttia miehistä ja 24 prosenttia naisista. Kansainvälisissä tutkimuksissa on raportoitu lääkäreiden ja mielenterveysalan työntekijöiden osalta 50 prosentin tai jopa 60 prosentin osuuksia.

Tutkimus on osoittanut, että työuupumus on melko krooninen tila hoitamattomana. Suomessa työuupumukseen on tarjottu kuntoutuskursseja niille työssäkäyville, joiden työkyky on ollut vaarantunut. Kuntoutusin- terventioilla on Suomessa pitkät perinteet. Taloudellinen tuki sekä työpaikan säilyminen kuntoutuksen aikana ovat tekijöitä, jotka toimivat kannustimena hakeutumisessa kuntoutuksen piiriin.

Työuupumusinterventiot voidaan luokitella kolmeen ryhmään: yksilösuuntautuneisiin (jolloin työuupumusta hoidetaan erilaisin rentoutus- ja tietoisuusmenetelmin, kognitiivis-käyttäytymisterapeuttisin keinoin ja lisäämällä itsehyväksyntää ja itsearmollisuutta); organisatorisiin (jolloin toteutetaan muutoksia työpaikalla, muutetaan työrakenteita ja parannetaan tiimin toimivuutta, johtajuutta ym.); ja näiden kahden yhdistelmiin. Systemaattiset katsaukset eivät ole tuottaneet yksiselitteisiä todisteita tietyn interventiotyypin tehokkuudesta muihin verrattaessa. Tietyt tutkimukset ovat osoittaneet, että yksilökeskeiset interventiot ovat tehokkaampia kuin organisaatiosuuntautuneet, kun taas osan mukaan molemmat interventiot tuottavat samansuuntaisia tuloksia tai organisaatiokeskeiset ovat tehokkaampia. On myös esitetty johtopäätöksiä, että yksilökeskeisillä interventioilla ei ole vaikutusta työuupumuksen lievittymiseen.

Vaikka työuupumusta on tutkittu suhteellisen pitkään ja laajasti, toipuminen siitä on edelleen alue, joka vaatii lisää tutkimusta. Tämän väitöskirjan kolmen osatutkimuksen tavoitteena oli tutkia yksilöllisiä kokemuk- 
sia työuupumuksesta toipumisesta kuntoutuskontekstissa. Tutkimuksessa selvitettiin työuupumuksesta toipumisen kokemusta kuntoutuskurssin aikana ja kaksi vuotta sen päättymisen jälkeen. Kolmantena tavoitteena oli tutkia työuupuneiden puolisoiden kokemuksia sekä työuupumuksesta että toipumisprosessista. Lisäksi tutkimus pyrki selvittämään miten nämä prosessit - työuupumus ja siitä toipuminen - vaikuttavat puolisoiden väliseen suhteeseen puolisoiden kokemana.

Tutkimuksen kannalta keskeiseksi nousi toimijuuden käsite. Toimijuus on määritelty luottamukseksi siihen, että ihminen voi saavuttaa tavoitteensa ja vaikuttaa ympäristöön. Toimijuutta on kolmea eri tyyppiä: henkilökohtaista, lähitoimijuutta ja kollektiivista. Henkilökohtainen toimijuus tarkoittaa uskoa siihen, että kukin voi itse saavuttaa halutut tavoitteet. Kun tämä ei ole mahdollista, voidaan turvautua läheisen henkilön tai esimiehen apuun. Kollektiivinen toimijuus heijastaa uskoa siihen, että tietyn ihmisryhmän resursseja ja ponnisteluja voidaan käyttää haluttujen tavoitteiden saavuttamiseksi. Kuntoutuskurssit pyrkivät nimenomaan kuntoutujan toimijuuden vahvistamiseen.

Osatutkimus I tarkasteli kahdentoista kuntoutujan kokemuksia toipumisesta kuntoutuskurssin aikana. Kuntoutujat rekrytoitiin tutkimukseen kolmelta eri kuntoutuskurssilta eräästä Keski-Suomen kuntoutuskeskuksesta. Kriteeri tutkimukseen osallistumiseen oli työuupumuspisteiden väheneminen ainakin yhdellä luokalla. Muutokset työuupumuspisteissä mitattiin Bergen Burnout Indicator (BBI-15) -kyselymenetelmällä. Tulokset osoittivat, että kuntoutujat hyötyivät kuntoutuskurssista. Sisällönanalyysi tuotti yhden yläteeman, Hyvinvointi omissa käsissäni, ja neljä kategoriaa: tuki, tietoisuus, hyväksyntä ja palautunut ilo. Yläteema kuvasi toipumisen kokonaisprosessia fyysisine ja psyykkisine muutoksineen ja ilmaisi kuntoutujien kokemaa oivallusta, että he itse ovat vastuussa omasta hyvinvoinnistaan. Muut kategoriat rakentuivat toistensa varaan kuvaten toipumisen prosessia. Tuki viittasi kuntoutusammattilaisilta sekä vertaistukiryhmästä saatuun kannustukseen. Kuntoutujat kokivat, että heidän kokemuksi- aan kuultiin ja ymmärrettiin validoiden näin heidän kokemaansa kärsimystä ja tuoden lohtua, etteivät he ole yksin. Tietoisuus kuvasi lisääntynyttä tietoa työuupumuksesta, sen oireista ja kulusta sekä korostunutta sensitiivisyyttä omaa kehoa ja mieltä kohtaan. Hyväksyntä sisälsi itsehyväksynnän ja itsearmon lisääntymisen sekä omien tarpeiden ja rajojen tunnistamista. Toipumisprosessi kulminoitui palautuneeseen elämäniloon, sosiaalisen vuorovaikutuksen elävöittämiseen ja uudenlaiseen asenteeseen työhön ja elämän prioriteetteihin.

Osatutkimus II laajensi tietoutta toipumisprosessista tutkimalla neljän kuntoutujan toipumisprosessin jatkoa ja toimijuuden ilmentymiä 1,5 ja 2 vuotta kuntoutuskurssin jälkeen. Tutkimuksessa tarkasteltiin kuntoutujien narratiiveja pitkittäistutkimusasetelmalla. Osallistujat tähän osatutkimukseen valittiin harkinnanvaraisella otannalla (purposeful sampling) noudattaen kahta kriteeriä: jatkunut toipuminen vs. pahentunut työuupumus sekä työpaikan vaihto vs. ei työpaikan vaihtoa. Tutkimukseen valittiin neljä kuntoutujaa, joista kaksi oli jatkanut toipumisen tiellä ja kahdella työuupumuspisteet olivat nousseet seurantajaksolla. Heistä kaksi oli vaihtanut työpaikkaa ja kaksi oli jäänyt edelliseen työpaikkaansa. Työpaikan vaihto ei välttämättä kuitenkaan taannut toipumispolulla pysymistä. Kokonaisuudessaan voi todeta, että toipumisen polut kuntoutuskurssin jälkeen olivat hyvin heterogeenisiä ja yksilöllisiä, mikä osoittaa työuupumuksen monisyisyyttä. Vaikuttaa siltä, että toipumisen polku oli suotuisin silloin, kun henkilökohtainen ja lähitoimijuus olivat vahvoja ja muut elämän osa-alueet, kuten esimies, työympäristö ja perheenjäsenet, edesauttoivat toipumista ja toipumisen polulla pysymistä. Työpaikan vaihto ei toisaalta osoittautunut ratkaisevaksi tekijäksi toipumisen pysyvyyden kannalta, vaan nimenomaan työpaikalla toteutetut muutokset tukivat toipumista tai johtivat työuupumuksen pahenemiseen.

Osatutkimus III tutki puolestaan osaaluetta, joka on jäänyt pitkälti tarkastelematta työuupumuskirjallisuudessa eli puolisoiden kokemuksia työuupumuksesta ja siitä toipumisen prosesseista. Työuupumusta on 
tutkittu pitkään yksilön tai organisaation näkökulmasta, mutta vaikutus perheenjäseniin ja tarkemmin puolisoihin on jäänyt lähes huomiotta. Tulokset osoittivat, että kokemukset asettuvat yksilö- ja parisuhdetasolle ja luonteeltaan ne olivat sekä negatiivisia että positiivisia. Temaattinen analyysi tuotti kolme teemaa yksilötasolla: puolisot turvasatamana, kuormitus puolisolla ja validaatio, ja kaksi teemaa parisuhdetasolla: sitoutuminen parisuhteeseen ja negativinen vaikutus parisuhteeseen. Puolisoilla oli tärkeä rooli erityisesti työuupumusvaiheessa, jolloin puolisot tarjosivat tukea, kompensaatiota ja ennaltaehkäisyä. Puolisot ottivat paljon vastuuta perheen ja talouden pyörittämisestä erityisesti silloin, kun työuupuneen kunto oli huonoimmillaan. Lisäksi puolisoilla oli mahdollisuus tarkastella työuupumusoireita riittävän läheisenä mutta silti ulkopuolisena tahona ja näin ehkäistä työuupumuksen uusiutumista. Kolikon kääntöpuolena puolisot kokivat paljon ahdinkoa työuupumuksen aikana ja joutuivat miettimään omaa hyvinvointiaan vetämällä rajoja puolison työuupumuksen ja oman mielenterveyden välille. Varsin tärkeänä teemana nousi esiin validaatio eli puolison kokemus kuulluksi tulemisesta kuntoutuskurssin puolisoille varattuna päivänä. Vaikka vain pieni osa puolisoista oli hyödyntänyt tätä mahdollisuutta, kokemukset siitä olivat hyvin myönteisiä ja vahvistivat puolisoiden toimintaa ja tekojen oikeellisuuden. Parisuhteen osalta puolisot kokivat, että työuupumus ei ole horjuttanut lojaliteettia puolisoa kohtaan, ja he olivat kaiken lisäksi löytäneet uusia merkityksiä ja mahdollisuuksia parantaa puolisoiden välistä kommunikaatiota ja avoimuutta. Negatiivisina seurauksina puolisot nostivat konfliktit sekä stagnaation parisuhteessa. Konflikti ei ollut vahingollisin seuraus vaan erityisen vaurioittavana nähtiin stagnaatio, sillä se tyrehdytti puolisoiden yhteisen ajan. Kaiken kaikkiaan työuupumus vaikutti parisuhteeseen lievemmin kuin oletettiin, minkä voi selittää osaltaan tutkimukseen valikoituminen: vain pariskunnat, joiden parisuhde oli vankalla pohjalla, osallistuivat vapaaehtoisesti tutkimukseen.

Kokonaisuudessaan väitöskirja osoitti, et- tä toipuminen työuupumuksesta on moniulotteinen prosessi, johon vaikuttaa usea tekijä. Kuntoutuskurssi oli omiaan käynnistämään toipumisen prosessia ja osa kuntoutujista kykeni ylläpitämään hyvinvointiaan esimerkiksi korkean henkilökohtaisen tai lähitoimijuuden ansiosta. Toipumisessa on kuitenkin äärimmäisen tärkeää huomioida muut elämän osa-alueet, erityisesti työympäristö, mutta myös perheeseen liittyvät tekijät. Voi todeta, että työuupumus vaikuttaa myös perheenjäseniin, vaikka se ei ole yhtä lamauttava kuin vakavat somaattiset tai mielenterveysongelmat.

Tulevan tutkimuksen täytyy kiinnittää entistäparemmin huomiota työuupumuksen laajakantoisiin vaikutuksiin ja kattavasti työuupuneiden työ- ja perheympäristöön. Kuntoutuskurssit olivat erittäin hyödyllisiä toipumisen prosessin käynnistämisessä, ja niiden turvaaminen myös tulevaisuudessa on suotavaa. Näihin ohjelmiin kuuluu tällä hetkellä perheenjäsenelle omistettu päivä, jota valitettavasti vain harvat käyttävät. Osallistumista tähän päivään olisi kannustettava, koska tällaisen päivän myönteiset vaikutukset ovat huomattavat ja ne voivat olla positiivinen lisä uupuneiden henkilöiden toipumiseen. Myös puolisoiden rooli voidaan ottaa paremmin huomioon työhön paluuta koskevissa säädöksissä ja ohjeissa.

Yhteiskunnallinen tavoite Suomessa on ollut pidentää työuria samalla kun yhä useampi jää pois työelämästä työuupumuksen tai masennuksen vuoksi. Näiden tavoitteiden saavuttamiseksi työuupumuksesta toipumisen mekanismeja tulee ymmärtää paremmin, jotta voitaisiin vaikuttaa juuri niihin, joilla toipumisen ylläpito on vaikeaa.

\section{Stela Salminen, PsM, VTM, KTK, psykologi, HUS}

Kirjoitus on yhteenveto kirjoittajan väitöstutkimuksesta "'Back on the right track': Rehabilitees' and spouses' experiences of burnout and recovery", joka tarkastettiin Jyväskylän yliopiston Kasvatustieteiden ja psykologian tiedekunnassa 7.5.2021. Väitös julkaistiin JYU Dissertations -sarjassa, numero 366. Saatavilla: http://urn.fi/URN: ISBN:978-951-39-8588-2 